\title{
A Study on the Usefulness of Audio-Visual Aids in EFL Classroom: Implications for Effective Instruction
}

\author{
Nalliveettil George Mathew ${ }^{1} \&$ Ali Odeh Hammoud Alidmat ${ }^{2}$ \\ ${ }^{1}$ Assistant Professor, Aljouf University, Saudi Arabia \\ ${ }^{2}$ Lecturer, Aljouf University, Saudi Arabia \\ Correspondence: Nalliveettil George Mathew, Assistant Professor, Aljouf University, Saudi Arabia. E-mail: \\ ngeorgemathew09@gmail.com
}

Received: March 5, 2013

Accepted: April 23, $2013 \quad$ Online Published: April 30, 2013

doi:10.5430/ijhe.v2n2p86

URL: http://dx.doi.org/10.5430/ijhe.v2n2p86

\begin{abstract}
A resourceful English language teacher equipped with eclecticism is desirable in English as a foreign language classroom. The challenges of classroom instruction increases when prescribed English as a Foreign Language (EFL) course books (textbooks) are constituted with too many interactive language proficiency activities. Most importantly, it has become a common phenomenon to integrate language textbooks with audio and video as additional or supplementary resources for classroom language learning activities. A study was conducted on the usefulness of audio-visual aids in EFL classroom at undergraduate level at Aljouf University, Saudi Arabia. Findings of the study give insights on EFL students' approach to using technological aids.

EFL textbooks with technological aids are often viewed to be an inspiration and to provide motivation in classroom instruction. However, a close examination of classroom teaching aids and resources unveil many issues in EFL teaching and learning contexts. Insights, issues and implications presented in the paper are useful to English language educators, administrators, curriculum designers and English teachers in English as a Foreign Language setting.
\end{abstract}

Keywords: EFL, Classroom, Audio-visual, Teaching, Learning

Abbreviation: EFL $=$ English as a Foreign Language

\section{Introduction}

A resourceful English language teacher with an eclectic approach is desirable in English as a foreign language classroom. An eclectic approach is characterized as a pluralistic approach to language teaching because it involves the use of a variety of language learning activities. Rivers (1981) advocated an eclectic approach in which teachers draw upon techniques from a variety of methodologies. According to Carlos Yorio (1987) an eclectic view of language teaching is the most sensible and the most sensitive way of approaching the language classroom. Language teachers use a variety of teaching aids to make classroom activities interesting and interactive. Teaching aids are important in the teaching-learning process. According to Ranasinghe and Leisher (2009), integrating technology into the classroom begins when a teacher prepare lessons that use technology in meaningful and relevant ways. Technological aids should support the curriculum rather than dominate it. Ranasinghe and Leisher say that technology should assist the teacher in creating a collaborative learning environment. Capper (2003) points out that many teachers who have access to the technology will not use it because they do not have technical knowledge and are satisfied with their current approach to teaching. He says that these teachers either find many difficulties while using technology or they do not have sufficient time to gather relevant lessons supported by technology. An effective integration of teaching aids and methodology elevates the learning environment. Koç (2005) says that the integration of technology into curriculum means using it as a tool to

teach academic subjects and to promote higher-order thinking skills of the students. Developments in technology gave scope for innovative practices in the classroom. Technical advances in the production of audio-visual aids for classroom use have been remarkable. Technological developments in Saudi Arabia had a positive impact on language learning environment. Educational reforms for improving English language skills initiated by the Ministry of Higher Education elevated the classroom learning environment in Saudi Arabia. University classrooms were equipped with world class technological teaching aids for making classroom teaching-learning process interesting 
and resourceful. The availability of fine equipment and simple operational modes made it easier for the teachers to use these aids in the classroom. Electronic gadgets like Smart-boards, LCD projectors and Digital Labs empowered teachers to make the teaching-learning process interactive and interesting. The English curriculum at undergraduate level also recommends the use of audio-visual aids for effective classroom instruction. Aljouf University is governed by the rules and regulations of the Ministry of Higher Education, Saudi Arabia. Ministry of Higher Education, Saudi Arabia has made it mandatory for an undergraduate student to complete eight semesters to get a graduate degree from the University. The courses for each academic degree are distributed across eight levels. The core courses, the elective courses, and the number of credits the student must successfully complete to earn the degree in his/her major are detailed for each level. A beginner at undergraduate level course has to successfully complete courses related to listening, speaking, reading and writing. Activities related to listening and speaking skills require audio-visual aids. It is the responsibility of the teacher to use audio-visual aids to make the teaching-learning process effective. Ranasinghe and Leisher (2009) points out that technology can never replace the human mind, but it can help expand it. They opine that teaching students how to use technology as a tool help their learning. Effective use of these technological aids depends on teacher motivation, interest, and availability of resources, technical knowledge and students' response towards these audio-visual aids.

According to Gilakjani (2011), the difficulties faced by EFL learners in classrooms are lack of motivation, lack of exposure to the target language, lack of emphasis on pronunciation by teachers and the influence of sounds and rules of learners' first language on English. Most of the EFL teachers are aware that native speakers' accent, rhythm and intonation used in the audio materials pose a difficulty to the undergraduate students. In this context it is important to have an awareness of students' approach towards audio-visual aids and resources. An understanding of students' views on these teaching aids gives scope for necessary modifications in the classroom teaching-learning process for effective audio- visual enrichment. Since audio-visual resources are designed and introduced to improve the language proficiency of the students, an understanding of how these resources are effective in classroom learning environment would be beneficial while designing and integrating audio-visual resources with EFL textbooks.

\section{Impact of technical and non-technical aids in EFL classroom}

EFL textbooks used with technological and methodological developments are often viewed as an inspiration and motivation in classroom instruction. A close examination of these resources unfolds many issues in EFL teaching and learning contexts. A beginning level course in English as a foreign language gives importance to the specific skills of listening, speaking, reading and writing. These language specific skills are interlinked with sub-skills like note taking, note making, paragraph writing and conversational skills. A macro view of these language skills indicates that EFL teacher need to be less laborious in the classroom. According to Kerr (1996), integrating technology into classroom practice requires a shift in both teaching style and the teacher's vision of what classroom life is all about. He points out that teachers who have the expertise in technology and are enthusiastic about using it confront obstacles like overly packed curricula and crowded classrooms. Audio - visual aids are different types of tools that appeal to the sense of learning and vision and are used in classrooms for presentation of abstract information. However, a language teacher in an EFL classroom experience challenging situations with the communicational activities given in the prescribed EFL textbooks. A study conducted by Park and Bae Son (2009) investigated factors affecting English as a Foreign Language teachers use of technological aids in the classroom in Korea. Findings of this study suggest that the quality of education does not depend on the use of technologies but depends exclusively on the quality of teachers. According to Park and Bae Son, the teachers who participated in this study are of the view that their positive attitude and continues attempt to introduce innovative technologies and teaching materials to the class enhances effective language learning instruction. This study reports that it is time-consuming for teachers to search for appropriate on-line EFL materials and integrate with textbooks to meet the levels and needs of students. Findings of the study suggest that technical aids have a significant role in EFL classroom. A study conducted by Maniruzzaman and Rahman (2008) on the use of audio aids in the EFL class at the tertiary level in Bangladesh suggest that lack of teacher training, insufficiency of audio equipment and material, and the indifference of administration hamper the use of audio aids in the EFL class. They are of the opinion that a foreign language learner may feel uninterested or disappointed with EFL course materials when they find it unfamiliar, difficult, problematic, mechanical and unattractive. Classroom environment should stimulate creativity, develop positive interests, attitudes and values for effective learning. Tasks and activities should be aimed to build essential skills such as independent study and capacity to think and judge for oneself. According to Lam (2000), teachers' personal beliefs of the advantages of using technology for language teaching influence teachers' decision regarding technology use.

Jadal (2011) conducted a study on effectiveness of the audio- visual aids in teaching and learning of English at primary Level in Z.P Primary Schools of Solapur District, India. Findings of the study suggest that many English teachers were 
found unable to use audio-visual equipments and materials. These teachers were not fully aware of the various projected aids to be used in the classroom. A study conducted by Morris (2011) on using technology in the EFL classroom in Saudi Arabia indicate that anxiety levels of students increase when they are asked to put away their computers and hand-in their cell phones. Morris says that students feel disconnected and focus more on the return of these important devices than they do on their language. He opines that computers, cellular phones, $4^{\text {th }}$ generation smart phones, information search engines, and social networking sites are being used and accessed by more than half of the world's population. Morris points out that the world has changed with these new technologies and so must EFL teachers and the EFL classroom. Keene (2006) says that information from video materials require processing different modes of communication which include a visual, verbal, sounds and subtitles. He is of the view that these kinds of materials can be used in a multi-skills lesson to enhance learner interaction through productive and receptive skills. A study conducted by Park and Bae Son (2009) in the EFL classroom in Korea indicate that teachers have positive and favourable attitudes toward the use of the computers. According to the findings of the study, teachers in EFL classroom consider computer technology as a useful teaching tool that can enhance ways of teaching by offering students a variety of language inputs and expanding students' learning experiences in real and authentic contexts. However, constraints reported by the study relate to external factors such as lack of time, insufficient computer facilities, rigid school curricula and textbooks. Dias (1999) argue that to make technology integral to their teaching, language teachers and their administrators must understand common barriers to technology integration and be prepared for the changes caused by technology integration. According to Dias, a fundamental challenge for EFL teachers is using technology to create innovative learning opportunities for students.

Language activities and tasks for language learning in the prescribed EFL textbooks can be a source of inspiration or frustration to the beginners of English. EFL teaching and learning becomes monotonous when the language teachers are compelled to rely on the textbooks as the only source of language input. According to Bude $\mathrm{Su}$ (2009), the instructional methods, classroom activities, the content delivery formats, the role of teachers and students need some level of modification when technology becomes an integral part in the classroom. Since prescribed textbooks are considered to be very important in language learning, an overview of the standard and informal procedures reveals the problems, success and failures in EFL teaching-learning contexts at the undergraduate level. The modernization of classroom teaching aids gave scope for teachers to go beyond chalk and talk method. LCD monitors, Smart Boards and interactive software programmes are commonly used in EFL classrooms at Aljouf University, Saudi Arabia. Current trends in classroom instruction forced educational institutions to make changes in the recruitment of teaching staff. In addition to the specific educational qualification, language teachers with computer knowledge are preferred by the government and non-governmental educational sectors across the world.

At Aljouf University, all the classrooms are equipped with electronic gadgets and smart boards. EFL teachers can use audio-visual resources during the classroom sessions because of the availability of LCD projectors and Smart Boards. The present study is intended to find out the usefulness of these technological teaching aids in EFL classroom.

\section{The Study}

The present study addresses and explores the following statements:

1) EFL Students' perception about the use of audio-visual aids in the classroom.

2) EFL Students' approach to audio-visual resources in the classroom.

\section{Research Design and Methodology}

\subsection{Subjects}

The study was conducted with 15 undergraduate students at Aljouf University, Saudi Arabia. All the students were native Arabs and their major at undergraduate level is English Language and Literature. The prescribed course books for most of these courses are integrated with audio-visual materials. Since the present study focuses on the use of audio-visual aids in the EFL classroom, it is important to elicit students' responses on the use of audio-visual resources in the teaching-learning process of English. Students were briefed that their responses are meant for research purposes and not related to their evaluation process.

\subsection{Questionnaire}

A combination of quantitative and qualitative method was used to address and explore research questions. It was felt that EFL students may be more comfortable to express their opinions in writing. A questionnaire was designed to obtain information on the use of audio-visual aids in the EFL classroom. Students were told that their responses would be used for research purposes only. The ten questions were related to the use of audio-visual aids during 
English language classroom sessions, its relevance for English classroom and interrelatedness to English course books. Most of the given questions were open ended and students were requested to express their views impartially. It was felt that open ended questions would give more insights by way of activating students' thought processes. Students were encouraged to seek researcher's help whenever they found a given question difficult to understand.

\section{Data analysis and Findings}

Data analysis of the students' questionnaire is presented with the findings. The response of the students is calculated in a percentage and given in tabular and non-tabular format.

\subsection{Items in the Questionnaire}

The questionnaire was administered over the sample of 15 undergraduate students in their sixth semester specializing in English language. Students were expected to respond to the questions in the form of writing. The questionnaire had open-ended and closed-ended questions. Question No. 1, 4 and 7 are close-ended questions where they are expected to answer in a word (yes/no). Question No. 2, 3, 5, 6, 8, 9 and 10 are open-ended questions where they are expected to respond based on their observation, knowledge and experience as undergraduate students. An analysis of students' response to the ten questions is presented below.

Table 1.

\begin{tabular}{llll}
\hline Question & Response & Score & Percentage \\
\hline $\begin{array}{l}\text { Do you find the need for the English teachers to use audio-visual aids in the } \\
\text { classroom? }\end{array}$ & Yes & 11 & 73.3 \\
& No & 4 & 26.6 \\
\hline
\end{tabular}

Table 1 indicates that most of the students find the need for the English teachers to use audio-visual aids in the classroom. However, 26.6\% did not find the need for the English teachers to use audio-visual aids in the classroom. This indicates that there are students who find the audio-video teaching sessions not very important in the English language classroom.

Students gave interesting responses to this question. A student noted that "some students cannot get the information in traditional ways but using audio-visual aids will help them to understand better". Other opinions related to improving English language skills by listening to native speakers and making the classroom sessions interesting. Students also felt that audio-visual aids can be useful when teachers find certain language terms difficult to explain on the white boards. EFL students are of the opinion that audio-visual aids can help their understanding.

Few students are of the opinion that teachers need not use audio-visual aids in the classroom. A student opined "that's because some teachers can bring more understanding to the students without the use audio-visual". These students are of the opinion that teachers can convey the idea without using audio-visual aids in the classroom. These students seem to be comfortable with traditional methods of teaching.

Table 2.

\begin{tabular}{llll}
\hline Question & Response & Score & Percentage \\
\hline Are audio-visual aids used in the English Language classroom? & Yes & 09 & 60 \\
& No & 06 & 40 \\
\hline
\end{tabular}

Response of the students indicates that most of them find English teachers in General English courses and specialized courses using audio-visual aids in the classroom. However, $40 \%$ of the students point out that English teachers do not use audio-visual aids in the EFL classroom. Since agreement and disagreement is too close, it is important to note that most of prescribed English Language course books are integrated with audio materials. There seems to be difference of opinion because in General English courses there are many teachers who teach in different sections of the university. Each of this teacher's has the autonomy to deliver the course content using a teaching methodology of their choice. Since each of these teachers vary in their teaching approach, undergraduate students studying General English courses shared their personal learning experiences. It was observed that some of the teachers do use audio-visual resources while few other teachers do not use audio-visual resources in the classroom. Instead, these few teachers read the listening texts aloud because they probably feel the accent and pace used in the audio-visual materials pose difficulty to students' comprehension.

An analysis of data indicates that only $10 \%$ of students responded to the fifth question (If yes, how are they related to your lesson?). Students who responded were not clear as to how these audio-visual resources are related to their lessons. A student observed "it is related in many ways by Power Point Program, some dictionaries programs, some 
audio or video shows". It is observed that few English teachers use Power Point Presentations for making classroom sessions lively. Use of audio visual clips in the classroom enhances students' receptive skills. Gorder (2008) points out that the difference between technology use and technology integration for learning is that integration implies frequent operation within lessons. Integrating technology with lessons of the course books can make the teaching-learning process more meaningful.

Data analysis indicates that only $10 \%$ of students responded to the sixth question (If no, why they are not used?). However, student pointed out "the teacher does not find CD containing that lesson". It was observed that in certain EFL course books, few tasks at the end of a lesson demand audio-visual resources but it is the responsibility of the teachers to search for resources in the web. Since these resources are not readily available on the web, teachers find audio-visual aids difficult to use in the classroom.

Students' response to the seventh question is given in the tabular form. In question 1, students responded to the question about the necessity of audio-visual aids for EFL classroom while the question 7 is related to the usefulness of audio-visual aids in the classroom teaching-learning process.

Table 3.

\begin{tabular}{llll}
\hline Question & Response & Score & Percentage \\
\hline Do you find the audio-visual aids useful? & Yes & 10 & 66.6 \\
& No & 05 & 33.3
\end{tabular}

Most of the students find audio-visual aids useful for the classroom. However, 33.3\% of students find audio-visual aids not useful for the classroom. Since most of audio recordings used for listening activities are based on native speakers of English, these students probably find vocabulary, accent and language structures difficult to comprehend.

Data analysis indicates that only $10 \%$ of students responded to the eighth question (If yes, how are they useful?). However, student pointed out that audio-visual material will help in improving pronunciation skills and conversational skills. Another student noted that audio-visual material can make a lesson easy to understand. Images that a student views on the screen can be easily comprehended and remembered than descriptive reading materials. Student felt that information can be retained for longer duration due to the use of audio-visual aids. However, most of the students did not respond to this question. It is perceived that these students were unable to articulate their thoughts in written form.

Since most of the students responded positively that audio-visual materials are useful for classroom, none of them answered to the ninth question (If no, why do you think they are not useful?). The few students who responded that audio-visual materials are not useful for the classroom also did not give their observations to this question. As mentioned earlier, it is perceived that an open ended question of this type posed difficulty for the EFL students.

Most of the students responded to the tenth question (Your suggestions about audio-visual aids in the English Language Classroom) giving suggestions on audio-visual aids in the English Language Classroom. A student noted "it should be used by the teachers because it is very helpful these days". EFL students are of the opinion that English teachers should have the requisite technical knowledge to operate audio-visual equipments during classroom sessions. They feel that teachers need to be educated on the use of these technical aids. In addition to their technical knowledge, English teachers should be trained in the selection and appropriate use of audio-visual resources. Another student noted "it is very good to our life because today all of our life depends on the technology". Students also pointed out that audio-visual aids are recommended for the classroom because it saves time and labor of the teacher

\section{Observations on EFL students' approach towards questionnaire}

Questionnaire used as a research tool for eliciting information about students' perception towards audio-visual aids and resources gave information on important issues of classroom teaching-learning process. In the informal interaction with the students, it was noted that this kind of questionnaires helped them to reflect on audio-visual aids and resources. English Language proficiency level of the students was considered while designing the questionnaire. In spite of the care taken to make questions simple and open ended, a few students found difficult to respond to some of the given questions. Other students also requested a translation of the given questions to Arabic as these open ended questions were beyond their comprehension. 


\section{Implications on EFL classroom}

The findings of the present study reveal that integrating audio-visual resources with the prescribed course content has a positive impact on the teaching-learning process in EFL classroom. Students find these resources useful in understanding difficult concepts given in the course books. They feel that use of these aids can increase retention. University Classrooms with latest technological aids and smart boards should be a source of inspiration for EFL teachers and learners. Findings of the present study supports the views of Alley and Jansak (2001) that the teachers' best strategy to prepare for teaching is to use learner-centered teaching principles, translate these principles into practices, and think creatively while using technology instruction methods. Utilizing these technological aids with innovative teaching practices can make the teaching-learning process more effective and interesting. To make audio-visual sessions effective, teachers need to experiment and test the resources prior to classroom instructions. Poor planning and failure on the part of a teacher to be self-literate about audio resources given in course book often end up in frustration. A good understanding of audio-visual resources can make the EFL classroom interactive. These resources are more appropriately used when new topics are being introduced in the classroom. During initial stages of integrating classroom sessions with technological aids, teachers may experience difficulties and failures. Teachers who find it hard to accept these failures may stop using technological aids in the classroom. When teachers fail to make effective use of these resources, students tend to find audio-visual aids irrelevant. Practicing EFL teachers should be given training in the effective use of audio-visual aids and resources. Individual teacher's self-awareness and expertise in the use of teaching-aids has a direct impact on the classroom environment. Moeller and Reitzes (2011) opine that in order to effectively use technology in their classroom, teachers need to hold a positive attitude. Students gain from a resourceful, interesting and learner-centered EFL classroom. During the classroom sessions, students observe the attitudes, teaching styles and innovative techniques of their teachers. Students form opinions and assumptions on daily-basis and a successful teacher has to meticulously integrate course content with technological aids for effective classroom instruction. Honey and Moeller (1990) state that an important element affecting how and whether teachers use technology in their classroom is their pedagogical beliefs on learning and instruction. A practicing teacher should realize that too much audio-visual material used at one time can result in boredom. Frustration and negative tendency may be visible in the students when the materials used in an audio-visual sessions are unsuited to their cognitive levels.

Use of audio-visual resources requires more care because it provides opportunities for effective communication between teachers and students in EFL classroom. Dawes (2001) rightly points out that new technologies have the potential to support education across the curriculum. EFL teachers should have deeper understanding in the selection and use of these resources. It is the responsibility of the teachers to check the quality and authenticity of these resources. On the positive side, the effective use of these aids saves time in learning and students can develop a keen observation and interest in classroom sessions. Relying too much on these audio-visual aids and resources during teaching sessions can lead to monotony and boredom. Considering that each teaching and learning situation varies, a teacher needs to have an understanding of the advantages of each aid and of combination of aids.

\section{Conclusion and Recommendations}

The findings of the study suggest that using audio-visuals as a teaching method stimulates thinking and improves learning environment in a classroom. Effective use of audio-visual aids substitutes monotonous learning environments. Students develop and increase personal understanding of the areas of learning when they experience a successful and pleasant learning in the EFL classroom. Findings suggest that students find audio-visual sessions useful and relevant when it has some direct relation to the course content. The present research gave insights on students' perception and opinions on the use of audio-visual aids and resources. However, it is also important to consider EFL teachers opinions, perceptions, experiences, failures and success while using audio-visual resources. A similar study can be conducted with more students and teachers to have an in-depth understanding of the successful use of audio-visual aids and resources in the EFL classroom.

\section{References}

Alley, L. R., \& Jansak, K. E. (2001). The ten keys to quality assurance and assessment in online learning. Journal of Interactive Instruction Development, 14(3), 3-18.

Bude Su. (2009). Effective technology integration: Old topic, new thoughts. International Journal of Education and Development using Information and Communication Technology, 5, (2), 161-171

Capper, J. (2003). Complexities and challenges of integrating technology in the curriculum. TechKnowLogia, 60-63.

Chan Nim Park \& Jeong-Bae Son. (2009). Implementing Computer-Assisted Language Learning in the EFL 
classroom: teachers' perceptions and perspectives. International Journal of Pedagogies and Learning, 5(2), 80-101. http://dx.doi.org/10.5172/ijpl.5.2.80

Dawes, L. (2001). What stops teachers using new technology? In M. Leask (ED.), Issues in teaching using ICT (pp.61-79). London: Routledge.

Dias, L.B. (1999). Integrating technology. Learning and Leading with Technology, 27, (3), 10-21.

Gilakjani, A. B. (2011). A study on the situation of pronunciation instruction in ESL/EFL classrooms. Journal of Studies in Education, 1, (1), 1-15.

Gorder, L. M. (2008). A study of teacher perceptions of instructional technology integration in the classroom. Delta Pi Epsilon Journal, 50 (2), 63-76

Honey, M., \& Moeller, B. (1990). Teachers' beliefs and technology integration: Different values, different understanding. New York: Center for Technology in Education.

Jadal, M. M, (2011). A study of effectiveness of the audio-visual-aids in teaching and learning of English at primary level in Z.P. Primary Schools of Solapur District. Indian Streams Research Journal I (VII). [Online] Available: http://www.isrj.net/August/2011/jadal_sir_A_Study_of_effectiveness.html

Kerr, S.T. (1996). Technology and the future of schooling: Ninety-fifth Yearbook of the National Society of the Study of Education. Chicago: University of Chicago Press.

Koç, M. (2005). Implications of learning theories for effective technology integration and pre-service teacher training: A critical literature review. Journal of Science Education, 2, (1), 1-16.

Lam, Y. (2000). Technophilia vs. technophobia: A preliminary look at why second-language teachers do or do not use technology in their classrooms. Canadian Modern Language Review, 56 (3), 390-420. http://dx.doi.org/10.3138/cmlr.56.3.389

Malcolm David Keene. (2006). Viewing Video and DVD in the EFL Classroom. Bunkyo Gakuin University Journal, Vol.8 (1), 217-234.

Maniruzzaman, M. \& M.M. Rahman. (2008). The use of audio aids in the EFL Class at the tertiary level: A plus or a minus? Daffodil University International Journal of Business and Economics, Vol. 3 (1), 121-137.

Moeller, B \& Reitzes, T. (2011). Integrating technology with student-centered learning. MA: Nellie Mae Education Foundation.

Neil Oby Morris .(2011). Using technology in the EFL Classroom in Saudi Arabia. AYMAT Individual Thesis/SMAT IPP Collection. Paper 511. [Online] Available: http://digitalcollections.sit.edu/cgi/viewcontent.cgi?article=1514\&context=ipp_collection

Ranasinghe, A. I. \& Leisher, D. (2009). The benefit of integrating technology into the classroom. International Mathematical Forum, 4, (40), 1955-1961.

Rivers, W. (1981). Teaching Foreign-Language Skills, 2nd Edition. Chicago, Ill.: University of Chicago Press.

Yorio, C. (1987). Building multiple bridges: Eclecticism in language teaching. TESL Canada Journal, 5, (1), 91-100.

\section{Questionnaire for Students}

1. Do you find the need for the English teachers to use audio-visual aids in the classroom? Yes/No

2. If yes, why do they need to use audio-visual aids in the classroom?

3. If no, why do you think they should not use audio-visual aids in the classroom?

4. Are audio-visual aids used in the English Language classroom? Yes/no

5. If yes, are they related to your lesson?

6. If no, why are they not used?

7. Do you find the audio-visual aids useful?

8. If yes, how are they useful?

9. If no, why do you think they are not useful?

10. Your suggestions about audio-visual aids in the English language classroom. 